\title{
Enantiomeric conformation controls rate and yield of photoinduced electron transfer in DNA sensitized by Ru(II) Dipyridophenazine complexes
}

Article

Accepted Version

Keane, P. M., Poynton, F. E., Hall, J. P., Clark, I. P., Sazanovich, I. V., Towrie, M., Gunnlaugsson, T., Quinn, S. J., Cardin, C. J. and Kelly, J. M. (2015) Enantiomeric conformation controls rate and yield of photoinduced electron transfer in DNA sensitized by Ru(II) Dipyridophenazine complexes. Journal of Physical Chemistry Letters, 6 (4). pp. 734-738. ISSN 1948-7185 doi: https://doi.org/10.1021/jz502743q Available at https://centaur.reading.ac.uk/40117/

It is advisable to refer to the publisher's version if you intend to cite from the work. See Guidance on citing.

Published version at: http://pubs.acs.org/doi/full/10.1021/jz502743q

To link to this article DOI: http://dx.doi.org/10.1021/jz502743q

Publisher: American Chemical Society

All outputs in CentAUR are protected by Intellectual Property Rights law, including copyright law. Copyright and IPR is retained by the creators or other copyright holders. Terms and conditions for use of this material are defined in 
the End User Agreement.

www.reading.ac.uk/centaur

\section{CentAUR}

Central Archive at the University of Reading

Reading's research outputs online 


\section{Enantiomeric Conformation Controls Rate and Yield of}

\section{Photo-induced Electron Transfer in DNA Sensitized by}

\section{Ru(II) Dipyridophenazine Complexes}

Páraic M. Keane ${ }^{a, b^{*}}$ Fergus E. Poynton, ${ }^{a, c}$ James P. Hall, ${ }^{b, d}$ Ian P. Clark, ${ }^{e}$ Igor V. Sazanovich, ${ }^{e}$ Michael Towrie, ${ }^{e}$ Thorfinnur Gunnlaugsson, ${ }^{a, c}$ Susan J. Quinn, ${ }^{f}$ Christine J. Cardin ${ }^{b^{*}}$ and John M. Kelly $^{a^{*}}$

${ }^{a}$ School of Chemistry, Trinity College, Dublin 2, Ireland
${ }^{b}$ Dept. of Chemistry, University of Reading, Whiteknights, Reading, RG6 6AD, UK

${ }^{c}$ Trinity Biomedical Science Institute, Pearse St., Dublin 2, Ireland

${ }^{d}$ Diamond Light Source, Harwell Science and Innovation Campus, Didcot, Oxfordshire, OX11 0QX, UK

${ }^{e}$ Central Laser Facility, Research Complex at Harwell, STFC Rutherford Appleton Laboratory, Harwell Science and Innovation Campus, Oxfordshire, OX11 0QX, UK

${ }^{f}$ School of Chemistry and Chemical Biology, University College Dublin, Dublin 4, Ireland

\section{AUTHOR INFORMATION}

\section{Corresponding Author}

*jmkelly@tcd.ie, keanepa@tcd.ie, c.j.cardin@rdg.ac.uk 


\section{ABSTRACT}

Photosensitized oxidation of guanine is an important route to DNA damage. Ruthenium polypyridyls are very useful photosensitizers as their reactivity and DNA-binding properties are readily tunable. Here we show a strong difference in the reactivity of the two enantiomers of $\left[\mathrm{Ru}(\mathrm{TAP})_{2}(\mathrm{dppz})\right]^{2+}$, by using timeresolved visible and IR spectroscopy. This reveals that the photosensitized one-electron oxidation of guanine in three oligonucleotide sequences proceeds with similar rates and yields for bound delta$\left[\mathrm{Ru}(\mathrm{TAP})_{2}(\mathrm{dppz})\right]^{2+}$, whereas those for the lambda enantiomer are very sensitive to base sequence. It is proposed that these differences are due to preferences of each enantiomer for different binding sites in the duplex.

\section{TOC GRAPHICS}

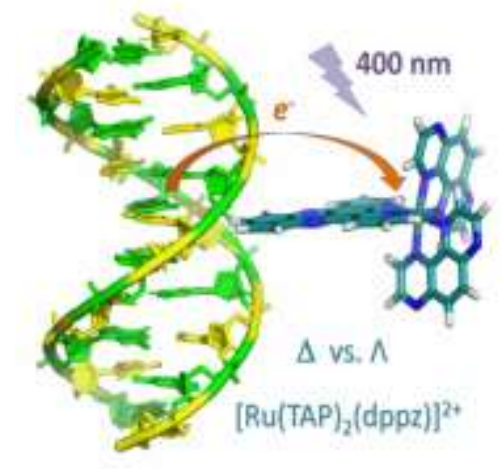

KEYWORDS Photo-oxidation, transient spectroscopy, nucleic acids, metal complexes, guanine

The photo-oxidation of guanine by small molecules is an important precursor to DNA damage, and a mechanism for possible novel photo-therapeutic applications. ${ }^{1-7} \mathrm{Ru}(\mathrm{II}) \mathrm{L}_{2}(\mathrm{dppz})$ complexes are DNA intercalators and those with the appropriate redox chemistry, such as $r a c-\left[\operatorname{Ru}(\mathrm{TAP})_{2}(\mathrm{dppz})\right]^{2+}(\mathbf{1})(\mathrm{TAP}$ $=$ 1,4,5,8-tetraazaphenanthrene; $d p p z=$ dipyrido[3,2-a: 2',3'-c]phenazine), can photo-oxidize guanine 
when bound. ${ }^{8-12}$ As DNA is chiral, enantiomers of octahedral metal complexes are expected to bind in different ways, with resulting effects on the excited-state behavior. ${ }^{13-15}$ Detailed knowledge of enantiomer binding has improved in recent years following the report of the crystal structure of $\Lambda_{-}$ $\left[\operatorname{Ru}(\mathrm{TAP})_{2}(\mathrm{dppz})\right]^{2+}$ intercalated into the $\{\text { TCGGCGCCGA }\}_{2}$ decamer duplex $(\mathbf{A})^{16}$ and several structures of the 'light switch' complexes $\left[\mathrm{Ru}(\mathrm{phen})_{2}(\mathrm{dppz})\right]^{2+}(\text { phen }=1,10 \text {-phenanthroline })^{17,18}$ or $\left[\mathrm{Ru}(\mathrm{bpy})_{2}(\mathrm{dppz})\right]^{2+}\left(\mathrm{bpy}-2,2^{\prime} \text {-bipyridyl }\right)^{19}$ bound to small DNA molecules. While there have been attempts to correlate the enantio-specificity of the luminescence of DNA-bound $\left[\mathrm{Ru}(\mathrm{phen})_{2}(\mathrm{dppz})\right]^{2+18,20-24}$ there has yet to be a transient spectroscopic study of how these structural factors affect guanine photo-oxidation in dppz complexes. In order to try to understand the influence of the handedness of the metal complex on the photo-oxidation of guanine when bound to DNA, we compare here the $\Lambda$ and $\Delta$ enantiomers of $\left[\operatorname{Ru}(\mathrm{TAP})_{2}(\mathrm{dppz})\right]^{2+}$ in oligodeoxynucleotide (ODN) $\left\{(\mathrm{GC})_{5}\right\}_{2}$ and $\left\{\mathrm{G}_{5} \mathrm{C}_{5}\right\}_{2}$, as well as in ODN A. As ODN A contains both $\mathrm{G}$ and GG sites, the two GC ODNs were chosen because they consist purely of either single or consecutive Gs, respectively (Figure 1)

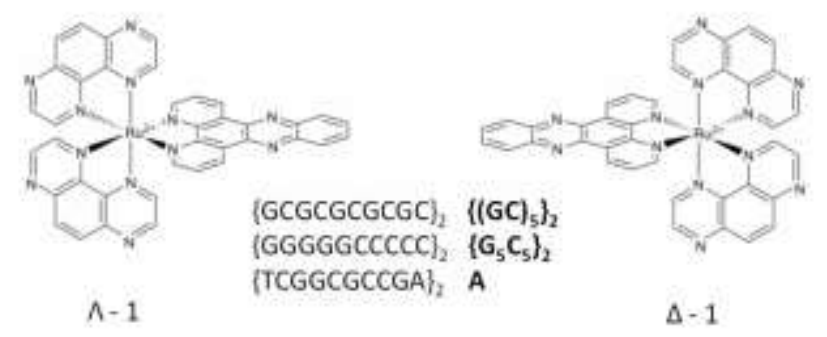

Figure 1 Structures of $\Lambda$ - and $\Delta-\left[\operatorname{Ru}(\mathrm{TAP})_{2}(\mathrm{dppz})\right]^{2+}$ and ODNs used in this study

The forward and reverse ET between the enantiomers of $\mathbf{1}$ and the ODNs were monitored using both transient absorption (TA) and time-resolved infrared (TRIR) spectroscopy on the ps and ns timescales. TA is especially useful for monitoring the transient species formed from the metal complex while TRIR is particularly sensitive to chemical changes in the DNA nucleobases. ${ }^{25-26}$ Samples were prepared at a Ru:duplex ODN ratio of 0.8:1 (400 $\mu \mathrm{M} \mathrm{Ru}, 500 \mu \mathrm{M}$ duplex) in buffered $\mathrm{D}_{2} \mathrm{O} .^{27}$ The ps-TA spectra of either $\Lambda \mathbf{- 1}$ or $\Delta \mathbf{- 1}$ bound to any of the three ODNs (Figure 2) shows the initial removal of the ground 
state at $460 \mathrm{~nm}$ (negative 'bleaching') and concurrent formation of a broad positive transient feature $\left(\lambda_{\max }=600 \mathrm{~nm}\right)$ immediately after photoexcitation of the Ru complex $(400 \mathrm{~nm}, 1 \mu \mathrm{J})$.

a)
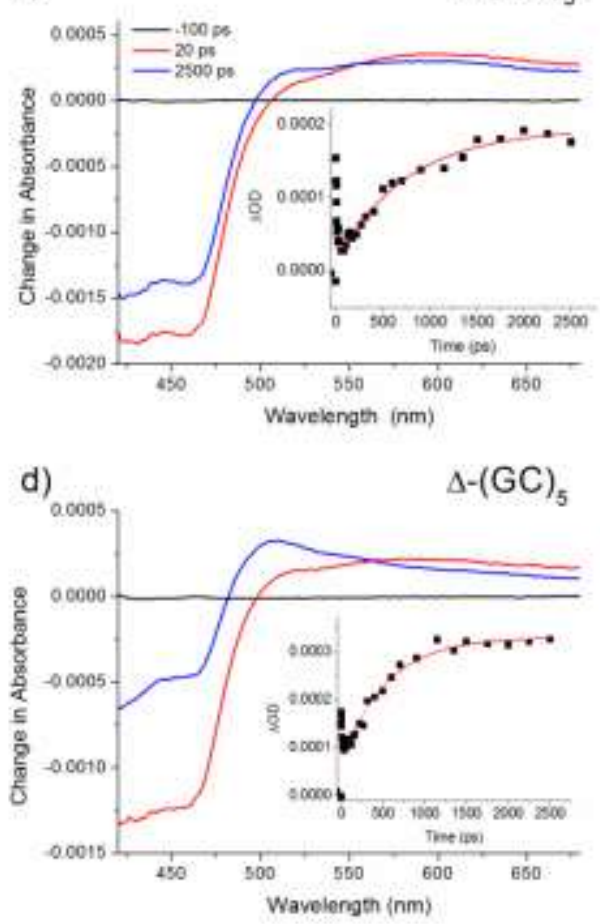

b)

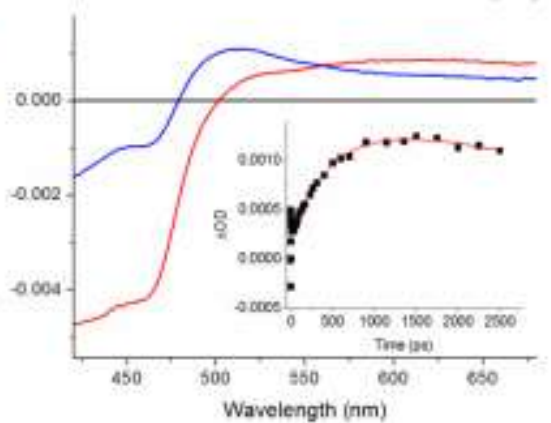

e)

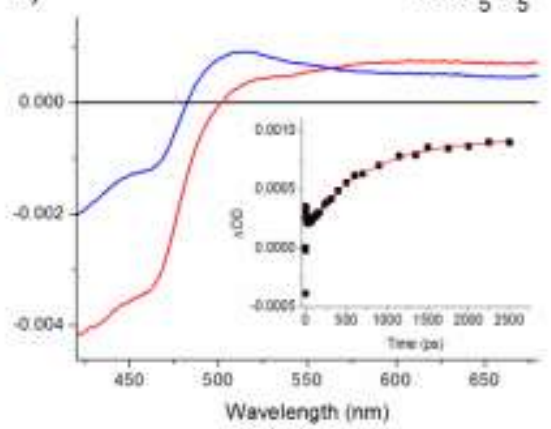

c)

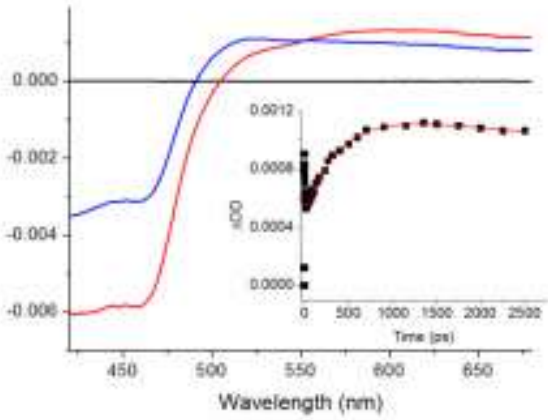

$\Delta-A$

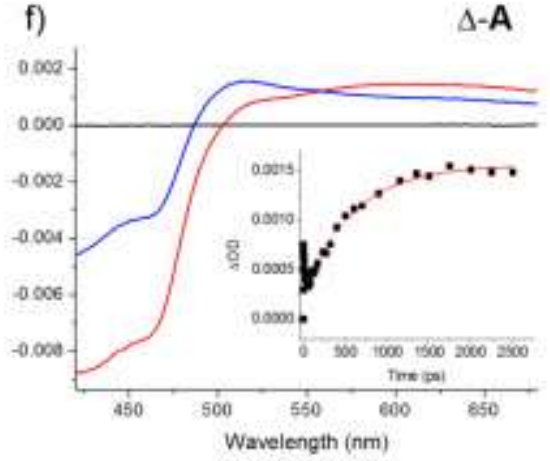

Figure 2. Selected ps-TA spectra (-100 ps, 20 ps, 2500 ps) and associated kinetic fits at $515 \mathrm{~nm}$ (inset) for $\Lambda$-[Ru(TAP) $\left.)_{2}(\mathrm{dppz})\right]^{2+}$ bound to (a) ) $\left\{(\mathrm{GC})_{5}\right\}_{2}(\mathrm{~b})\left\{\mathrm{G}_{5} \mathrm{C}_{5}\right\}_{2}$ (c) $\mathbf{A}$; and $\Delta-\left[\mathrm{Ru}(\mathrm{TAP})_{2}(\mathrm{dppz})\right]^{2+}$ bound to (d) $\left\{(\mathrm{GC})_{5}\right\}_{2}(\mathrm{e})\left\{\mathrm{G}_{5} \mathrm{C}_{5}\right\}_{2}$ (f) A. In each case $\lambda_{\text {exc }}=400 \mathrm{~nm}, 1 \mu \mathrm{J}$. [Ru] $=400 \mu \mathrm{M},[\mathrm{ODN}]=500 \mu \mathrm{M}$ duplex in $50 \mathrm{mM}$ phosphate $(\mathrm{pH} 7)$ in $\mathrm{D}_{2} \mathrm{O}$ with $50 \mu \mathrm{m}$ pathlength

This transient feature is assigned as the $\left[\mathrm{Ru}^{\mathrm{III}}(\mathrm{TAP})\left(\mathrm{TAP}^{\bullet-}\right)(\mathrm{dppz})\right]^{2+}{ }^{3} \mathrm{MLCT}$ state (also observed in unbound complex; ESI Figure S2). This excited state is much more readily reduced than the corresponding ground-state complex $\left(\mathrm{E}^{\mathrm{o}^{*}}=1.44 \mathrm{~V} \text { vs NHE}\right)^{2 \mathrm{c}}$ and accordingly causes the 'grow in' of a new feature at $515 \mathrm{~nm}$, assigned to the reduced complex $\left[\mathrm{Ru}^{\mathrm{II}}(\mathrm{TAP})\left(\mathrm{TAP}^{\bullet-}\right)(\mathrm{dppz})\right]^{+}$. By comparing the strength of this signal with that of the initially formed excited state (at $600 \mathrm{~nm}$ ), it is possible to compare relative ET yields between different systems. ${ }^{28}$

A comparison of $\Lambda \mathbf{- 1}$ or $\Delta \mathbf{- 1}$ bound to $\left\{(\mathrm{GC})_{5}\right\}_{2}$ reveals striking differences between the enantiomers (Figure 2a,d). Measuring the $515 \mathrm{~nm}: 600 \mathrm{~nm}$ absorbance ratio shows that the yield 
of reduced species is ca. 2.5 times higher for $\Delta-1$ than for $\Lambda-1$. By contrast, in the presence of $\left\{\mathrm{G}_{5} \mathrm{C}_{5}\right\}_{2}$ both $\Lambda \mathbf{- 1}$ or $\Delta \mathbf{- 1}$ show similarly high ET yields (Figure 2b,e). Rate constants for the electron transfer to the excited state range from $1 / 550 \mathrm{ps}^{-1}-1 / 770 \mathrm{ps}^{-1}$ (Table 1). The results with mixed sequence ODN A show intermediate behavior for the yield but not for the rate of the electron transfer process.(Figure 2c,f).

Table 1. ET parameters for $\Lambda-1$ and $\Delta-1$ bound to ODNs

\begin{tabular}{|c|c|c|c|c|c|c|}
\hline & \multicolumn{2}{|c|}{$\tau_{515 \mathrm{~nm}}$ forward (ps) } & \multicolumn{2}{|c|}{$\tau_{515 \mathrm{~nm}}$ reverse $(\mathrm{ns})$} & \multicolumn{2}{|c|}{ rel. yield ${ }^{\mathrm{a}}$} \\
\hline & $\Lambda$ & $\Delta$ & $\Lambda$ & $\Delta$ & $\Lambda$ & $\Delta$ \\
\hline$(\mathrm{GC})_{5}$ & $760 \pm 80$ & $650 \pm 70$ & $12 \pm 2$ & $7.5 \pm 0.7$ & 0.5 & 1.1 \\
\hline $\mathrm{G}_{5} \mathrm{C}_{5}$ & $550 \pm 70$ & $770 \pm 80$ & $5.5 \pm 0.6$ & $7.9 \pm 0.8$ & 1.2 & 1.0 \\
\hline $\mathbf{A}$ & $410 \pm 40$ & $730 \pm 70$ & $17 \pm 3$ & $8 \pm 1$ & 0.7 & 1.1 \\
\hline
\end{tabular}

${ }^{\mathrm{a}}$ relative yield defined as $\Delta \mathrm{OD}_{515 \mathrm{~nm}(1 \mathrm{~ns} \text { delay })} / \Delta \mathrm{OD}_{600 \mathrm{~nm}(1 \mathrm{ps} \text { delay })}{ }^{28}$

In order to monitor the subsequent decay of the reduced $\mathrm{Ru}$ species, TA experiments were recorded on the nanosecond timescale (see Figure 3 and ESI Figure S5). Kinetic fits at $515 \mathrm{~nm}$ (Table 1) show that the loss of the reduced species occurs with a similar rate for $\Delta \mathbf{- 1}$ bound to all three sequences $(8 \pm 1 \mathrm{~ns})$. By contrast, $\Lambda \mathbf{- 1}$ showed significant differences in reverse ET rate between the three sequences ranging from $5.5 \mathrm{~ns}\left(\left\{\mathrm{G}_{5} \mathrm{C}_{5}\right\}_{2}\right)$ to $17 \mathrm{~ns}(\mathrm{ODN} \mathbf{A})$. The $\left\{\mathrm{G}_{5} \mathrm{C}_{5}\right\}_{2}$ system is the only one where reverse ET is more efficient for $\Lambda \mathbf{- 1}$ than $\Delta-\mathbf{1}$ 


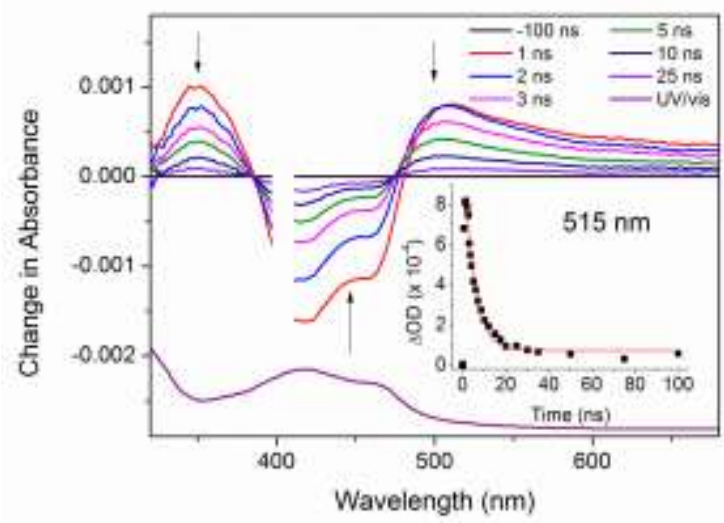

Figure 3. Ns-TA spectrum of $400 \mu \mathrm{M} \Lambda$-[Ru(TAP $\left.)_{2}(\mathrm{dppz})\right]^{2+}$ in the presence of $500 \mu \mathrm{M}$ $\left\{\mathrm{G}_{5} \mathrm{C}_{5}\right\}_{2}$ with corresponding ground state spectrum. Inset: monoexponential kinetic fit at $515 \mathrm{~nm}$. $\lambda_{\mathrm{exc}}=400 \mathrm{~nm}, 1 \mu \mathrm{J}$ (region around $400 \mathrm{~nm}$ removed due to scatter from laser). In $50 \mathrm{mM}$ phosphate $(\mathrm{pH} 7)$ in $\mathrm{D}_{2} \mathrm{O}$ with $50 \mu \mathrm{m}$ pathlength.

Measurements were then performed in the IR region to observe the effects on the DNA. As DNA does not absorb the $400 \mathrm{~nm}$ pulse, any DNA features present in the TRIR spectra must arise due to a photosensitized process. The ps-TRIR spectra for $\Lambda-\mathbf{1}$ with $\left\{\mathrm{G}_{5} \mathrm{C}_{5}\right\}_{2}$ is shown in Figure 4 (see also ESI Figures S6 \& S7).

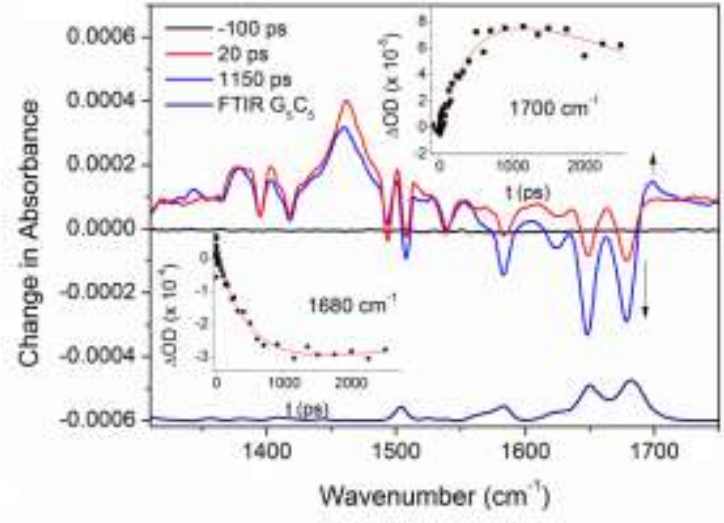


Figure 4. Ps-TRIR spectrum of $400 \mu \mathrm{M} \Lambda$-[Ru(TAP) $\left.)_{2}(\mathrm{dppz})\right]^{2+}$ in the presence of $500 \mu \mathrm{M}$ $\left\{\mathrm{G}_{5} \mathrm{C}_{5}\right\}_{2}$ with ground-state FTIR of $\left\{\mathrm{G}_{5} \mathrm{C}_{5}\right\}_{2}$ Inset: exponential fits to grow-in of $\mathrm{G}$ carbonyl bleach at $1680 \mathrm{~cm}^{-1}$ and $\mathrm{G}$ radical cation at $1700 \mathrm{~cm}^{-1} \lambda_{\text {exc }}=400 \mathrm{~nm}, 1 \mu \mathrm{J}$. In $50 \mathrm{mM}$ phosphate (pH 7) in $\mathrm{D}_{2} \mathrm{O}$ with $50 \mu \mathrm{m}$ pathlength

The majority of the features below $1500 \mathrm{~cm}^{-1}$ arise due the metal complex. Above $1500 \mathrm{~cm}^{-1}$ bleaching bands are observed that correspond to DNA nucleobase vibrations. At early times $(<$ $20 \mathrm{ps}$ ), bleaches are observed at $1650 \mathrm{~cm}^{-1}$ and $1680 \mathrm{~cm}^{-1}$, the regions where the $\mathrm{C}=\mathrm{O}$ bands of $\mathrm{C}$ and $\mathrm{G}$ absorb, respectively. These bands recover somewhat but then re-bleach over a 1-2 ns timescale, corresponding to a decrease in the population or intensity of $\mathrm{C}=\mathrm{O}$ stretching bands due to photo-oxidation of guanine in the GC base-pair. Kinetic fits to these bands yield rates that are similar to those measured by TA (in $\left\{\mathrm{G}_{5} \mathrm{C}_{5}\right\}_{2} \tau$ at $1680 \mathrm{~cm}^{-1}$ is $460 \pm 70$ ps for $\Lambda-1,970 \pm 150$ ps for $\Delta-1$; ESI Figure S7 \& Table S1)). Notably, there is also formation of a transient species at $1700 \mathrm{~cm}^{-1}$, which has been assigned as the $\mathrm{G}$ radical cation ${ }^{29}$ formed from the photosensitized oxidation of a guanine base by the Ru complex. A kinetic fit to the growth of this feature gives a rate $(430 \pm 80 \mathrm{ps})$ consistent with that recorded from the bleach of the $\mathrm{G}$ band and from the psTA spectra. This absorption has been observed in directly UV- excited GC systems, ${ }^{30-31}$ and has also been observed in the case of polynucleotide-bound Re dppz complexes, ${ }^{32}$ providing direct evidence for $\mathrm{G}$ oxidation that is difficult to obtain by $\mathrm{UV} /$ visible techniques. Where experiments were performed in the ns region (for $\Lambda-\mathbf{1}$ and $\Delta-\mathbf{1}$ with ODN $\mathbf{A}$ ), these bands recovered with rates similar to those recorded by TA (recovery of G bleach at $1680 \mathrm{~cm}^{-1}$ is $15 \pm 3 \mathrm{~ns}$ for $\Lambda-1$ and 
$11 \pm 2 \mathrm{~ns}$ for $\Delta-\mathbf{1}$; ESI Figures S8 \& S9 and Table S1) confirming that the decay of the reduced $\mathrm{Ru}$ complex corresponds to back electron transfer to oxidized DNA.

The main observation between the three sequences is that $\Lambda-1$ shows a large variation in yield of reduced species, and in rate of back electron transfer, while these parameters are all similar for $\Delta$-1. To explain this behavior we considered whether we can predict, using available crystal structures, how the electron transfer processes depend on the geometry at the binding site. The relevant structures determined by our group have been predominately with the lambda enantiomer. For this isomer the preferred intercalation site is at a pyr.C/G.pur base-pair $\left(\mathrm{TC} / \mathrm{GA}^{16} ; \mathrm{CC} / \mathrm{GG}^{17}\right)$. It may be noted that the dppz ligand shows good overlap with both purines in the GG or GA step (Figure 5a), as measured by the angle $\left(60^{\circ}\right)$ between the long axis of the dppz ligand and the P-P vector.
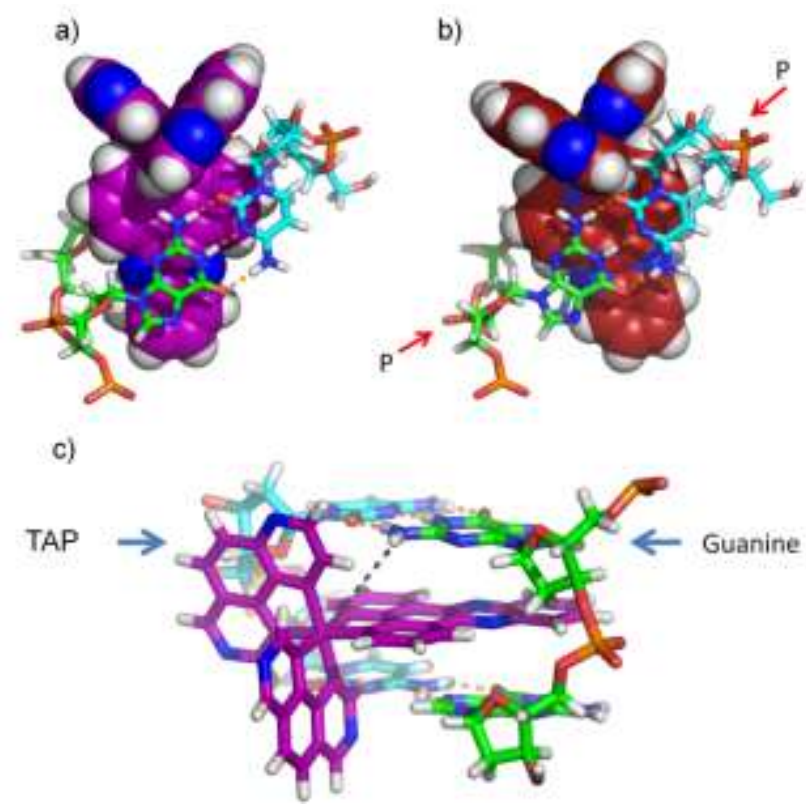

Figure 5. (a) Canted intercalation of $\Lambda$-[Ru(TAP $\left.)_{2}(\mathrm{dppz})\right]^{2+}$ at $\mathrm{GG} / \mathrm{CC}$ step in $\{\text { CCGGATCCGG }\}_{2}$, obtained using the crystal structure of $\Lambda$ - $\left[\operatorname{Ru}(\text { phen })_{2}(\mathrm{dppz})\right]^{2+}$ in the same sequence with phen ligands replaced by $\mathrm{TAP}^{5 \mathrm{a}}$ and (b) derived model for the $\Delta$ enantiomer in the same GG/CC step showing more symmetric binding and less overlap with G. The phosphates 
used to define the intercalation angle are also highlighted; (c) view showing Ru-guanine and TAP-guanine orientation and separation in (a)

However, for the delta enantiomer, modeling into the same step (Figure 5b) gives an increase in the angle to $75^{\circ}$, with an attendant decrease in the extent of overlap between the purine chromophores and the dppz ligand with consequent reduction in binding affinity. ${ }^{33}$ We therefore propose that for $\Delta \mathbf{- 1}$, if only a single binding site is occupied, ${ }^{34}$ it is preferentially at a GC/GC step. As this step is common to all three sequences, this may explain why the parameters for electron transfer are similar for the delta enantiomer in each sequence. Our previous X-ray structural work also show this site is disfavored by the lambda enantiomer. ${ }^{17}$ Note also that for symmetrical steps such as $\mathrm{GC} / \mathrm{GC}$ and $\mathrm{CG} / \mathrm{CG}$, we have shown that the overlap of the dppz ligand with guanine is less than in the case of the lambda enantiomer with GG/CC, and this will be the case at any symmetrical step. ${ }^{17}$ This may account for the substantial differences in electron transfer yield for the lambda enantiomer in $\left\{(\mathrm{GC})_{5}\right\}_{2}$ compared to $\left\{\mathrm{G}_{5} \mathrm{C}_{5}\right\}_{2}$. We suggest therefore that binding to GG steps may account for some of the difference observed for $\Lambda-\mathbf{1}$, due to the lower oxidation potential of consecutive Gs compared to a single G. ${ }^{35}$ As the oxidation potential is likely to be lower even further for a run of $5 \mathrm{Gs}$, this may partially explain the trend in ET yield for $\Lambda-1$ bound to the three sequences $(5 \mathrm{G}>2 \mathrm{G}>1 \mathrm{G})$. Interestingly, while there are significant changes in yield in these three systems, the rates of forward ET do not vary to the same extent, and do not always correlate with the changes in yield (for example the rate of forward ET is slower for $\Lambda-1$ bound to $\left\{\mathrm{G}_{5} \mathrm{C}_{5}\right\}_{2}$ compared to ODN A). A possible explanation tis that the complex is bound at various sites - in some of which the forward electron transfer is fast, whereas in others the rate is slow and on a timescale comparable to the back electron transfer. 
It may be noted that for other reported intercalator systems the yields and rates of ET are not necessarily proportional. ${ }^{37}$. In the case of $\left[\mathrm{Ru}(\mathrm{TAP})_{2}(\mathrm{dppz})\right]^{2+}$, the electron transfer is likely to occur to the metal centre, suggesting that forward ET may be determined by the Ru-G distance (4.6 $\AA$ in the structure in Fig. 5c). However if the dppz ligand is involved, the degree of coupling between the dppz and $\pi$-stacked guanine moiety may be important, and the rates and yields may be determined by a subtle interplay of Ru-G separation and the overlap of the guanine and dppz systems.

Although initial reduction occurs at the Ru metal centre, the extra electron in the reduced complex is known to be localized on the TAP ligands, ${ }^{9}$ hence the rate of reverse ET may be affected by the orientation and separation of the TAP ligand relative to the nearest guanine (see Figure 5c). The most efficient reverse transfer observed is for $\Lambda-1$ in the presence of $\left\{\mathrm{G}_{5} \mathrm{C}_{5}\right\}_{2}$. This may be due to the proximity of the TAP ligand to the $5^{\prime} \mathrm{G}$ of the G-run. By contrast, the TAP ligands in $\Delta-1$ is closer to $\mathrm{C}$ if the complex is bound at the GC/GC step. The rate of back electron transfer, and TAP-guanine orientation, is also likely to influence the possible formation of any permanent photoadduct, such as the TAP-guanine adduct formed from $\left[\mathrm{Ru}(\mathrm{TAP})_{2}(\mathrm{bpy})\right]^{2+}$ in the presence of $\mathrm{DNA}^{6,37}$ (as can be seen in Figure 5c, the TAP ligand is orthogonal to guanine.) However it is not clear at present whether the differences observed in transient spectroscopy result in enantioselective DNA damage, although it is noteworthy that higher yields of reduced species are sometimes accompanied by a more rapid reverse transfer in our measurements, which may protect DNA from permanent damage.

In summary, this work reveals striking difference in the behavior of the two enantiomers and demonstrates the complexity in the reactivity of $\mathrm{Ru}(\mathrm{II})$ complexes with DNA. We hope that our understanding of the structural factors influencing these processes may be aided by X-Ray crystallography as more structures are resolved. 


\section{ASSOCIATED CONTENT}

Supporting Information. Full experimental details, additional ns-TA and ps/ns-TRIR spectra and kinetic fits. This material is available free of charge via the Internet at http://pubs.acs.org.

\section{AUTHOR INFORMATION}

\section{Corresponding Author}

*Email:*jmkelly@tcd.ie, keanepa@tcd.ie, c.j.cardin@rdg.ac.uk

\section{Notes}

The authors declare no competing financial interests.

\section{ACKNOWLEDGMENT}

This work was supported by Royal Irish Academy/Royal Society exchange program (to CJC, JMK and TG), BBSRC grant BB/K019279/1 (CJC), EU/STFC for access to the CLF (App 12240002 and 13230047), Science Foundation Ireland (TG) and the Irish Research Council (FEP), and UCD (SJQ)

\section{REFERENCES}

(1) Puckett, C. A.; Barton, J. K. Methods to Explore Cellular Uptake of Ruthenium Complexes. J. Am. Chem. Soc. 2007, 129, 46-47

(2) Elmes, R. B. P.; Orange, K. N.; Cloonan, S. M.; Williams, D. C; Gunnlaugsson, T. Luminescent Ruthenium(II) Polypyridyl Functionalized Gold Nanoparticles; Their DNA Binding Abilities and Application As Cellular Imaging Agents. J. Am. Chem. Soc. 2011, 133, 1586215865 
(3) Gill, M. R; Thomas, J. A. Ruthenium(II) Polypyridyl Complexes and DNA--From Structural Probes to Cellular Imaging and Therapeutics. Chem. Soc. Rev. 2012, 41, 3179-3192

(4) Smith, N. A.; Sadler, P. J. Photoactivatable Metal Complexes: From Theory to Applications in Biotechnology and Medicine. Phil. Trans. R. Soc. A 2013, 371, 20120519.

(5) Wachter, E.; Heidary, D. K.; Howerton, B. S.; Parkin, S.; Glazer, E. C. Light-Activated Ruthenium Complexes Photobind DNA and are Cytotoxic in the Photodynamic Therapy Window. Chem. Commun. 2012, 48, 9649-9651

(6) Marcélis, L.; Moucheron, C.; Kirsch - De Mesmaeker, A. Ru-TAP Complexes and DNA: From Photo-induced Electron Transfer to Gene Photo-silencing in Living Cells. Phil. Trans. R. Soc. A 2013, 20120131

(7) Palmer, A. M.; Burya, S. J.; Gallucci, J. C.; Turro, C. Photoinduced Intercalation and Coordination of a Dirhodium Complex to DNA: Dual DNA Binding. ChemMedChem 2014, 9, $1260-1265$

(8) Lecomte, J.-P.; Kirsch-DeMesmaeker, A.; Feeney, M. M.; Kelly, J. M. Ruthenium(I1) Complexes with 1,4,5,8,9,12-Hexaazatriphenylene and 1,4,5,8-Tetraazaphenanthrene Ligands: Key Role Played by the Photoelectron Transfer in DNA Cleavage and Adduct Formation. Inorg. Chem. 1995, 34, 6481-6491

(9) Coates, G. C.; Callaghan, P.; McGarvey, J. J.; Kelly, J. M.; Jacquet, L.; KirschDeMesmaeker, A. Spectroscopic Studies of Structurally Similar DNA-Binding Ruthenium(II) Complexes Containing the Dipyridophenazine Ligand. J. Mol. Struct. 2001, 598, 15-25

(10) Ortmans, I.; Elias, B.; Kelly, J. M.; Moucheron, C.; Kirsch-DeMesmaeker, A. $\left[\operatorname{Ru}(\mathrm{TAP})_{2}(\mathrm{dppz})\right]^{2+}$ : A DNA Intercalating Complex, which Luminesces Strongly in Water and Undergoes Photo-induced Proton-coupled Electron Transfer with Guanosine-5'-Monophosphate. Dalton Trans. 2004, 668-676 
(11) Elias, B.; Creely, C.; Doorley, G. W.; Feeney, M. M.; Moucheron, C.; Kirsch-De Mesmaeker, A.; Dyer, J.; Grills, D. C.; George, M. W.; Matousek, P.; Parker, A. W.; Towrie, M.; Kelly, J. M. Photooxidation of Guanine by a Ruthenium Dipyridophenazine Complex Intercalated in a Double-Stranded Polynucleotide Monitored Directly by Picosecond Visible and Infrared Transient Absorption Spectroscopy. Chem. Eur. J. 2008, 14, 369-375

(12) Smith, J. A.; George, M. W.; Kelly, J. M. Transient Spectroscopy of Dipyridophenazine Metal Complexes which Undergo Photo-induced Electron Transfer with DNA. Coord. Chem. Rev. 2011, 255, 2666-2675

(13) Barton, J. K.; Danishevsky, A. T.; Goldberg, J. M. Tris(phenanthroline)ruthenium(II): Stereoselectivity in Binding to DNA. J. Am. Chem. Soc. 1984, 106, 2172-2176

(14) Zeglis, B. M.; Pierre, V. C.; J. Barton, J. K. Metallo-Intercalators and Metallo-Insertors. Chem. Commun. 2007, 4565-4579

(15) Liu, H.-K.; Sadler, P. J. Metal Complexes as DNA Intercalators. Acc. Chem. Res. 2011, 44, 349-359

(16) Hall, J. P.; O’Sullivan, K.; Naseer, A.; Smith, J. A.; Kelly, J. M.; Cardin, C. J. Structure Determination of an Intercalating Ruthenium Dipyridophenazine Complex which Kinks DNA by Semiintercalation of a Tetraazaphenanthrene Ligand. Proc. Natl. Acad. Sci. (USA) 2011, 108, 17610-17614

(17) Niyazi, H.; Hall, J. P.; O’Sullivan, K.; Winter, G.; Sorensen, T.; Kelly, J. M.; Cardin, C. J. Crystal Structures of $\Lambda$-[Ru(phen $\left.)_{2} \mathrm{dppz}\right]^{2+}$ with Oligonucleotides Containing TA/TA and AT/AT Steps Show Two Intercalation Modes. Nature. Chem. 2012, 4, 621-628

(18) Hall, J. P.; Cook, D.; Morte, S. R.; McIntyre, P.; Buchner, K.; Beer, H.; Cardin, D. J.; Brazier, J. A.; Winter, G.; Kelly, J. M.; Cardin, C. J. X-ray Crystal Structure of rac- 
$\left[\mathrm{Ru}(\mathrm{phen})_{2} \mathrm{dppz}\right]^{2+}$ with d(ATGCAT) $)_{2}$ Shows Enantiomer Orientations and Water Ordering. $J$. Am. Chem. Soc. 2013, 135, 12652-12659

(19) Song, H.; Kaiser, J. T.; Barton, J. K. Crystal Structure of $\Delta-\left[R u(b p y)_{2} d p p z\right]^{2+}$ Bound to Mismatched DNA Reveals Side-by-Side Metalloinsertion and Intercalation. Nature Chem. 2012, $4,615-620$

(20) Hiort, C.; Lincoln, P.; Norden, B. DNA Binding of $\Delta$ - and $\Lambda$ - $\left[R u(p h e n)_{2} D P P Z\right]^{2+} . J . A m$. Chem. Soc. 1993, 115, 3448-3454

(21) Haq, I.; Lincoln, P.; Suh, D.; Norden, B.; Chowdhry, B. Z.; Chaires, J. B. Interaction of $\Delta$ and $\Lambda-\left[\operatorname{Ru}(\text { phen })_{2} \mathrm{DPPZ}\right]^{2+}$ with DNA: A Calorimetric and Equilibrium Binding Study. $J . A m$. Chem. Soc. 1995, 117, 4788-4796

(22) McKinley, A. W.; Andersson, J.; Lincoln, P.; Tuite, E. DNA Sequence and Ancillary Ligand Modulate the Biexponential Emission Decay of Intercalated $\left[\mathrm{Ru}(\mathrm{L})_{2} \mathrm{dppz}\right]^{2+}$ Enantiomers. Chem. Eur. J. 2012, 18, 15142-15150

(23) McKinley, A. W.; Lincoln, P.; Tuite, E. M. Sensitivity of $\left[R u(p h e n)_{2} d p p z\right]^{2+}$ Light Switch Emission to Ionic Strength, Temperature, and DNA Sequence and Conformation. Dalton Trans. 2013, 42, 4081-4090

(24) Andersson, J.; Fornander, L. H.; Abrahamsson, M.; Tuite, E.; Nordell, P.; Lincoln, P. Lifetime Heterogeneity of DNA-Bound dppz Complexes Originates from Distinct Intercalation Geometries Determined by Complex-Complex Interactions. Inorg. Chem. 2013, 52, 1151-1159

(25) Towrie, M.; Doorley, G. W.; George, M. W.; Parker, A. W.; Quinn, S. J.; Kelly, J. M. psTRIR Covers all the Bases - Recent Advances in the use of Transient IR for the Detection of Short-lived Species in Nucleic Acids. Analyst, 2009, 134, 1265-1273 
(26) Schreier, W. J.; Schrader, T. E.; Koller, F. O.; Gilch, P.; Crespo-Hernández, C. E.; Swaminathan, V. N.; Carell, T.; Zinth, W.; Kohler, B. Thymine Dimerization in DNA Is an Ultrafast Photoreaction. Science, 2007, 315, 625-629

(27) These concentrations, and $\mathrm{D}_{2} \mathrm{O}$ solvent, were chosen to allow TA and TRIR experiments to be recorded on the same sample. Steady-state titrations at $7 \mu \mathrm{M} 1$ show strong binding and emission quenching for all ODNs with $\Lambda \mathbf{- 1}$ or $\Delta \mathbf{- 1}$. Binding appeared slightly weaker for $\Delta-\mathbf{1}$ in $\left\{\mathrm{G}_{5} \mathrm{C}_{5}\right\}_{2}$ (similar to that observed with $\left.\mathrm{rac}-\left[\mathrm{Cr}(\mathrm{phen})_{2}(\mathrm{dppz})\right]^{2+}\right) .^{38}$

(28) The rationale for using the $\Delta \mathrm{OD}_{515} \mathrm{~nm} / \Delta \mathrm{OD}_{600} \mathrm{~nm}$ ratio is given in the Supporting Information. For $\Lambda \mathbf{- 1}$ with ODN A, spectral profile and kinetics were unchanged at $250 \mathrm{~nJ}, 500$ $\mathrm{nJ}$ and $1 \mu \mathrm{J}$ pump laser energy, implying that multiphoton effects do not affect observed TA dynamics (ESI Figure S3). TA experiments for this system at various Ru:duplex ratios show that unbound Ru only becomes apparent at higher binding ratios (ESI Figure S4).

(29) Parker, A. W.; Lin, C. Y.; George, M. W.; Towrie, M.; Kuimova, M. K. Infrared Characterization of the Guanine Radical Cation: Finger Printing DNA Damage. J. Phys. Chem. B 2010, $114,3660-3667$

(30) Kuimova, M. K.; Cowan, A. J.; Matousek, P.; Parker, A. W. Sun, X. Z., Towrie, M.; George, M. W. Monitoring the Direct and Indirect Damage of DNA Bases and Polynucleotides by Using Time-Resolved Infrared Spectroscopy. Proc. Natl. Acad. Sci USA 2006, 103, 21502153

(31) Bucher, D. B.; Pilles, B. M.; Carell, T.; Zinth,W. Charge Separation and Charge Delocalization Identified in Long-Living Dtates of Photoexcited DNA. Proc. Natl. Acad. Sci USA 2014, 111, 4369-4374 
(32) Cao, Q.; Creely, C. M; Davies, E. S.; Dyer, J; Easun, T. K.; Grills, D. C.; McGovern, D. A; McMaster, J.; Pitchford, J.; Smith, J. A.; Sun, X.-Z.; Kelly, J. M; George, M. W. Excited State Dependent Electron Transfer of a Rhenium-Dipyridophenazine Complex Intercalated Between the Base Pairs of DNA: a Time-Resolved UV-Visible and IR Absorption Investigation into the Photophysics of $f a c-\left[\operatorname{Re}(\mathrm{CO})_{3}\left(\mathrm{~F}_{2} \mathrm{dppz}\right)(\mathrm{py})\right]+$ Bound to either $[\mathrm{poly}(\mathrm{dA}-\mathrm{dT})]_{2}$ or $[\operatorname{poly}(\mathrm{dG}-\mathrm{dC})]_{2}$

(33) The derived model was obtained by replacing $\Lambda$ with $\Delta$ (superimposed on the dppz ligand) and rotating the complex around the Ru metal centre until the bad contacts of the TAP ligands are removed. In the model this represents the minimum angle that the delta complex must rotate, relative to lambda, to be accommodated in the same intercalation site. The model is not a calculation or computer simulation, but serves to illustrate how the reversal in enantiomeric conformation is likely to affect the angle of intercalation and resulting overlap of the dppz ligand with the guanine base. We used a similar approach when comparing the $\Lambda$ and $\Delta$ $\left[\mathrm{Ru}(\text { phen })_{2}(\mathrm{dppz})\right]^{2+}$ co-crystallized in $\mathrm{d}(\mathrm{ATGCAT})_{2}{ }^{18}$

(34) Studies with $\{\text { poly }(\mathrm{dA}-\mathrm{dT})\}_{2}$ have found that allosteric binding may be significant for $\Lambda$ $\left[\mathrm{Ru}(\text { phen })_{2}(\mathrm{dppz})\right]^{2+}$, though such studies have not been reported with GC polymers. ${ }^{24}$

(35) Saito, I.; Nakamura, T.; Nakatani, K.; Yoshioka, Y.; Yamaguchi, K.; Sugiyama, H. Mapping of the Hot Spots for DNA Damage by One-Electron Oxidation: Efficacy of GG Doublets and GGG Triplets as a Trap in Long-Range Hole Migration. J. Am. Chem. Soc. 1998, $120,12686-12687$

(36) Wan, C.; Fiebig, T.; Kelley, S. O.; Treadway, C. J.; Barton, J. K.; Zewail, A. H. Femtosecond Dynamics of DNA-Mediated Electron Transfer Proc. Natl. Acad. Sci USA, 1999, $96,6014-6019$ 
(37) Jacquet, J.; Davies, R. J. H.; Kirsch-De Mesmaeker, A.; Kelly, J. M. Photoaddition of $\mathrm{Ru}(\operatorname{tap})_{2}(\mathrm{bpy})^{2+}$ to DNA: A New Mode of Covalent Attachment of Metal Complexes to Duplex DNA. J. Am. Chem. Soc. 1997, 119, 11763-11768

(38) Devereux, S. J.; Keane, P. M.; Vasudevan, S.; Sazanovich, I. V.; Towrie, M.; Cao, Q.; Sun, X.-Z.; George, M. W.; Cardin, C. J.; Kane-Maguire, N. A. P.; Kelly, J. M.; Quinn, S. J. Study of Picosecond Processes of an Intercalated Dipyridophenazine Cr(III) Complex Bound to Defined Sequence DNAs Using Transient Absorption and Time-Resolved Infrared Methods. Dalton

Trans. 2014, 43, 17606-17609 